\title{
U⿱宀⿻三丨口
}

\section{Amnesties' Challenge to the Global Accountability Norm? Interpreting Regional and International Trends in Amnesty Enactment}

Mallinder, L. (2012). Amnesties' Challenge to the Global Accountability Norm? Interpreting Regional and International Trends in Amnesty Enactment. In F. Lessa, \& L. A. Payne (Eds.), Amnesty in the Age of Human Rights Accountability: Comparative and International Perspectives (pp. 69-96). Cambridge University Press.

Link to publication record in Ulster University Research Portal

Published in:

Amnesty in the Age of Human Rights Accountability: Comparative and International Perspectives

Publication Status:

Published (in print/issue): 17/05/2012

\section{Document Version}

Author Accepted version

\section{General rights}

Copyright for the publications made accessible via Ulster University's Research Portal is retained by the author(s) and / or other copyright owners and it is a condition of accessing these publications that users recognise and abide by the legal requirements associated with these rights.

\section{Take down policy}

The Research Portal is Ulster University's institutional repository that provides access to Ulster's research outputs. Every effort has been made to ensure that content in the Research Portal does not infringe any person's rights, or applicable UK laws. If you discover content in the Research Portal that you believe breaches copyright or violates any law, please contact pure-support@ulster.ac.uk. 


\section{AMNESTIES' CHALLENGE TO THE GLOBAL ACCOUNTABILITY NORM? INTERPRETING REGIONAL AND INTERNATIONAL TRENDS IN AMNESTY ENACTMENT ${ }^{1}$}

\section{LOUISE MALLINDER ${ }^{2}$}

It is widely acknowledged that during the last decades of the twentieth century, the engagement of states with international human rights norms underwent a significant transformation. ${ }^{3}$ Evidence for this can be seen in states' involvement in the creation of new human rights institutions and international treaties. For example, with the entry into force of human rights instruments such as Optional Protocol to the International Covenant on Civil and Political Rights (in 1976) ${ }^{4}$ and the American Convention on Human Rights (in 1978), ${ }^{5}$ participating nation states empowered human rights monitoring institutions to investigate individual complaints of state responsibility for human rights violations, even when the complaints were made by their own citizens. In addition, through the agreement of treaties such as the Convention against Torture, ${ }^{6}$ states created new transnational offences that state parties were obliged to prevent and punish. Furthermore, in addition to submitting themselves

\footnotetext{
${ }^{1}$ An earlier version of this paper was presented at Amnesty in the Age of Accountability: Brazil in Comparative and International Perspective conference, University of Oxford, 23 October 2010. The author thanks the conference participants for their valuable feedback.

${ }^{2}$ Transitional Justice Institute, University of Ulster, 1.mallinder@ulster.ac.uk.

${ }^{3}$ See eg Chandra Lekha Sriram, "Revolutions in Accountability: New Approaches to Past Abuses," American University International Law Review 19, no. 2 (2003): 301-429.

${ }^{4}$ Optional Protocol to the International Covenant on Civil and Political Rights, G.A. res. 2200A (XXI), 999 U.N.T.S. 302, entered into force March 23, 1976.

${ }^{5}$ American Convention on Human Rights, 1144 U.N.T.S. 123, entered into force July 18, 1978.

${ }^{6}$ Convention against Torture and Other Cruel, Inhuman or Degrading Treatment or Punishment, U.N. Doc. A/39/51 (1984), entered into force June 26, 1987.
} 
to greater scrutiny on their adherence to human rights, states have also increasingly sought to promote human rights overseas through rule of law programmes, ${ }^{7}$ and cooperation with an ever-increasing range of international and hybrid criminal courts that hold individual perpetrators accountable for serious violations of human rights and humanitarian law. ${ }^{8}$ These forms of state behaviour were mirrored by an increased emphasis on human rights and the rule of law among international policymakers following the end of the Cold War. ${ }^{9}$ In a ground-breaking article in 2001, Lutz and Sikkink labelled these developments cumulatively as a 'justice cascade'. ${ }^{10}$

In developing the 'justice cascade' theory, Lutz and Sikkink relied primarily on developments in Latin America from the late 1970s to the late 1990s. They argued that during this period the region underwent 'a rapid shift toward recognising the legitimacy of the human rights norms and an increase in international and regional action to effect compliance with these norms'. ${ }^{11}$ Furthermore, pointing to the creation of the International Criminal Court in 1998 and increasing acceptance by domestic judges in several countries of the principle of universal jurisdiction for serious human rights violations, the authors argued that the justice cascade was 'not limited to Latin America', but was also 'reverberating internationally'. ${ }^{12}$

\footnotetext{
${ }^{7}$ See eg Vera Gowlland-Debbas and Vassilis Pergantis, "Rule of Law," in Post-Conflict Peacebuilding: A Lexicon, ed. Vincent Chetail (Oxford: Oxford University Press, 2009); Giovanni Bassu, "Law Overruled: Strengthening the Rule of Law in Postconflict States," Global Governance 14 (2008), 22-38.

${ }^{8}$ See eg Sarah Williams, Hybrid and Internationalised Criminal Tribunals (Oxford: Hart Publishing, 2011).

${ }^{9}$ See eg S. Humphreys, Theatre of the Rule of Law: Transnational Legal Intervention in Theory and Practice (Cambridge: Cambridge University Press, 2010).

${ }^{10}$ Ellen L. Lutz and Kathryn Sikkink, "The Justice Cascade: The Evolution and Impact of Foreign Human Rights Trials in Latin America," Chicago Journal of International Law 2, no. 1 (2001): 1-34.

${ }^{11}$ Ibid. 4.

12 Ibid. 4.
} 
These findings have been supported by other scholars who refer to the existence of 'revolutions in accountability' ${ }^{13}$ or an 'age of accountability'. 14

In relation to amnesty laws, the 'justice cascade' theory appears to suggest that, as the relevant human rights norms spread around the world, fewer amnesty laws that violate these norms will be enacted and where pre-existing amnesty laws come into conflict with evolving norms, they will be eroded or annulled. ${ }^{15}$ However, the data collected to support the justice cascade focuses on the growth in trials to hold human rights violators to account. ${ }^{16}$ It does not document or explain the continued use of amnesty laws internationally that has been highlighted by this author and other scholars. ${ }^{17}$ Drawing on the data compiled by the author

\footnotetext{
${ }^{13}$ See eg Sriram, Revolutions in Accountability.

${ }^{14}$ See eg Tricia D. Olsen, et al, "Amnesty in the Age of Accountability” (paper presented at the Annual Meeting
} of the Law and Society Association, Chicago, 2010).

${ }^{15}$ Drawing on literature on customary international law, the investigation of the existence of a global accountability norm could entail investigating a broad range of issues relating to amnesty laws, such as the existence or absence of relevant domestic legislation (either granting amnesties or requiring prosecutions); the derogation, annulment or reinterpretation of amnesties; state practice in relation to mediating peace agreements that include or exclude amnesty provisions or to financial and diplomatic support for amnesty processes; state willingness to include provisions prohibiting amnesty in international conventions; voting patterns in UN General Assembly resolutions; or judgements of domestic courts. However, such a broad analysis is beyond the scope of this paper, which will instead focus on rates the introduction of amnesty laws, the contexts that give rise to amnesties and the resulting scopes of the amnesty legislation.

${ }^{16}$ Hunjoon Kim and Kathryn Sikkink, "Explaining the Deterrence Effect for Human Rights Prosecutions for Transitional Countries," International Studies Quarterly 54, 4 (2010): 939-963.

${ }^{17}$ See eg Louise Mallinder, Amnesty, Human Rights and Political Transitions: Bridging the Peace and Justice Divide (Oxford: Hart Publishing, 2008); Mark Freeman, Necessary Evils: Amnesties and the Search for Justice (Cambridge: Cambridge University Press, 2010); Charles P. Trumbull, "Giving Amnesties a Second Chance," Berkeley Journal of International Law 25 (2007): 283-345; Tricia D. Olsen et al, Transitional Justice in 
in the Amnesty Law Database, this chapter will seek to address this gap by describing regional and global trends in amnesty law enactment and interpreting the existence of a global accountability norm in light of these trends. It will begin by discussing how 'mapping' amnesty laws through a large-N, comparative study can contribute to transitional justice knowledge. It will then briefly outline how the concept of amnesties has been defined within the Amnesty Law Database, and the data categorisation and collection processes used to construct this database. In the following section, the findings from the database will be used to present an overview of regional and international trends in amnesty law enactment from 1979 to 2011 . This section will focus in particular on the period since the agreement of the Rome Statute in $1998,{ }^{18}$ as this is often pointed to as a watershed event in the development of a global accountability norm. It is beyond the scope of this chapter to highlight trends in relation to all aspects of amnesty law scope and legal effects. Instead, it will focus on whether contemporary amnesties are more likely to exclude or include crimes under international law from their scope, which is a central issue to understandings of the 'justice cascade'. In the final section, the chapter will interpret the implications of these trends on the existence of such a cascade.

\section{WHY 'MAP' AMNESTY LAWS?}

Amnesty laws have played a central role in addressing political crises and violent conflicts for millennia. ${ }^{19}$ However, they have rarely been subjected to extensive comparative study. Instead, the literature has focused predominantly on in-depth studies of particular amnesty

Balance: Comparing Processes, Weighing Efficacy (Washington DC: United States Institute of Peace Press, 2010).

${ }^{18}$ Rome Statute of the International Criminal Court, 2187 UNTS 90, entered into force July 1, 2002.

${ }^{19}$ See eg Robert Parker, "Fighting the Siren's Song: The Problem of Amnesty in Historical and Contemporary Perspective," Acta Juridica Hungaria 42, no. 1/2 (2001): 69-89. 
processes, ${ }^{20}$ or since the 1990 s, on the relationship between amnesty laws and states' duties to investigate and prosecute under international law. ${ }^{21}$ These studies have provided significant insights into how distinct forms of amnesties have operated in particular countries and on the parameters of the international legal framework relating to amnesties. However, they left considerable gaps in transitional justice knowledge on the causes, scope, legal effects and impact of amnesty laws.

For example, as is common to transitional justice literature in general, the majority of in-depth country studies on amnesty laws focused on a handful of countries, notably Argentina and South Africa. As a result, these high-profile cases shaped much of the scholarly and practitioner debate on the nature of acceptable amnesties and on their impact on victims and societies. However, focusing on such single cases or small sets of cases can provide data with limited global applicability. ${ }^{22}$ For example, the amnesties in Argentina and South Africa were enacted following democratic elections, which creates different political dynamics and legitimacy than amnesties proclaimed in the midst of warfare. Furthermore, in both countries, even though the former regimes had severely corroded the rule of law, formal legal processes were nonetheless familiar to wide sections of population, whereas in other transitional contexts, traditional or community-based forms of justice may have greater

\footnotetext{
${ }^{20}$ See eg Jeremy Sarkin, Carrots and Sticks: The TRC and the South African Amnesty Process (Antwerp: Intersentia, 2004); Helena Cobban, Amnesty After Atrocity? Healing Nations After Genocide and War Crimes (Boulder, CO: Paradigm Publishers, 2007).

${ }^{21}$ See eg Andreas O’Shea, Amnesty for Crime in International Law and Practice (Hague: Kluwer Law International, 2002); Faustin Z. Ntoubandi, Amnesty for Crimes Against Humanity Under International Law (Leiden: Brill, 2007).

${ }^{22}$ Oskar N. T. Thoms, James Ron and Roland Paris, "State-Level Effects of Transitional Justice: What do we Know?" International Journal of Transitional Justice 4, no. 3 (2010): 329-354, 336.
} 
resonance for many affected peoples. ${ }^{23}$ In addition, both Argentina and South Africa experienced distinctive forms of human rights violations in the policy of widespread enforced disappearances and the repressive apartheid regime. These experiences differ from the crimes committed in other transitional contexts. The focus on individual cases in the Americas and Sub-Saharan Africa has also meant that the literature has neglected the role of amnesties in other regions, notably Asia and the Middle East. This gap is particularly significant because, as will be discussed below, both regions currently have higher rates of new amnesty law enactment than the Americas.

The gaps created by the relative absence of large- $\mathrm{N}$ comparative studies on the scope of amnesty laws are also problematic, as knowledge of trends in the scope of amnesty laws is crucial to understanding whether customary international law is evolving to prohibit certain forms of amnesty laws. In recent years, international jurists and scholars have increasingly made proclamations on the status of amnesty laws under customary international law, but few have based their assertions on extensive comparative studies of state practice. ${ }^{24}$ Indeed, by relying on a small number of cases, many of these analyses have overlooked the continued prevalence and endurance of amnesties around the world.

Of the few large-N comparative studies of amnesty laws conducted to date, the first was a United Nations' report prepared by Louis Joinet in 1985. This influential report sought to 'set out the practices followed by states dealing with amnesties', with the understanding

\footnotetext{
${ }^{23}$ See eg Rosalind Shaw and Lars Waldorf, eds., Localizing Transitional Justice: Interventions and Priorities After Mass Violence (Palo Alto: Stanford University Press, 2010); Luc Huyse and Mark Salter, eds., Traditional Justice and Reconciliation After Violent Conflict: Learning from African Experiences (Stockholm: International IDEA, 2008).

${ }^{24}$ For a more detailed discussion of this argument, see Louise Mallinder, "Peacebuilding, the Rule of Law and the Duty to Prosecute: What Role Remains for Amnesties?” in Building Peace in Post-Conflict States, ed Faria Medjouba (London: British Institute of International and Comparative Law, 2011).
} 
that such comparative research could contribute to 'deducing a number of rules or constants which might serve as a framework for authorities proposing to initiate an amnesty, as well as to the jurists responsible for drafting legislation'. ${ }^{25}$ The report further stated that ' $[t]$ his frame of reference might also be of use to the experts of the various specialised international supervisory bodies, in order to enable them to better assess the impact - positive, negative or nil - of an amnesty law' and for non-governmental organisations (NGOs). ${ }^{26}$ As explored below, this technical analysis of the nature on amnesty laws is similar to the approach pursued in the Amnesty Law Database as rather than treating amnesty laws as a homogenous group, it distils consideration of amnesty laws into distinct factors such as how and why amnesties are enacted, the crimes and categories of individuals covered, and the legal effects of amnesties.

It is interesting to note that, although Lutz and Sikkink date the origins of the 'justice cascade' to the early 1980s, when the UN Sub-Commission on Prevention of Discrimination and Protection of Minorities commissioned the Joinet report in 1983, it stated that it had become aware of the importance that the promulgation of amnesty laws 'could have for the safeguard and promotion of human rights and fundamental freedoms'.${ }^{27}$ In the final report, the positive role was described as including not just releasing all political prisoners, ${ }^{28}$ but also encouraging 'national consensus in the wake of political change brought about in a

\footnotetext{
${ }^{25}$ Louis Joinet, 'Study on Amnesty Laws and their role in the safeguard and protection of human rights' SubCommission on the Prevention of Discrimination and Protection of Minorities (United Nations Economic and Social Council 21 June 1985) E/CN.4/Sub.2/1985/16, para 85.

${ }^{26}$ Ibid, para 86.

${ }^{27}$ UN Sub-Commission on Prevention of Discrimination and Protection of Minorities, Resolution 1983/34 The administration of justice and the human rights of detainees. UN Doc E/CN.4/Sub.2/RES/1983/34 (6 September 1983).

${ }^{28}$ Joinet, 'Study on Amnesty Laws', para 81.
} 
democratic framework'; the 'first act in the initiation of a democratic process'; and blocking 'an internal crisis' or marking 'the end of an international armed conflict'. ${ }^{29}$

In the years following the Joinet report, amnesty laws became increasingly controversial and this contributed to the UN publicly changing its position on amnesties at the signing of the 1999 Lomé Accord which sought to end the conflict in Sierra Leone. ${ }^{30}$ Despite this growing controversy, no further large-N studies of amnesties were conducted until the mid-2000s, at which point, a few were launched by academics and conflict resolution practitioners. However, these studies only provided a partial picture of how amnesty laws are used around the world. For example, the comparative studies of peace agreements conducted by Bell ${ }^{31}$ and by Vinjamuri and Boesenecker ${ }^{32}$ highlight state practice in relation to amnesties only within peace agreements. In addition, neither these studies, nor the Transitional Justice Data Base Project, which compiles quantitative data on a range of transitional mechanisms enacted globally between 1970 and 2009, differentiate between different forms of amnesty laws. ${ }^{33}$ Instead, these projects adopt a universal operating definition of amnesties that can be applied across all contexts being investigated, but does not take into account the different forms of amnesty and the impact these differences can have on the law's impact in a transition.

\footnotetext{
${ }^{29}$ Ibid, para 7.

${ }^{30}$ See eg William A. Schabas, “Amnesty, the Sierra Leone Truth and Reconciliation Commission and the Special Court for Sierra Leone,” U.C. Davis Journal of International Law \& Policy 11 (2004): 145-169.

${ }^{31}$ See Christine Bell, On the Law of Peace: Peace Agreements and the Lex Pacificatoria (Oxford: Oxford University Press, 2008).

${ }^{32}$ Leslie Vinjamuri and Aaron Boesenecker, Accountability and Peace Agreements: Mapping Trends from 1980 to 2006 (Geneva: Centre for Humanitarian Dialogue 2007).

${ }^{33}$ Olsen et al, Transitional Justice in Balance.
} 
As will be explored below, the Amnesty Law Database (ALD) can be distinguished from the other comparative studies on amnesties in relation to its research purposes and design. In particular, it was not developed with the aim of testing hypotheses regarding the causes or impacts of amnesty laws. Instead, it sought to address the gaps outlined above in transitional justice knowledge of amnesty laws by developing thicker descriptions of the forms that these laws take, where they are being enacted and their legal effects. In this way, the purpose of the ALD is primarily to 'map' or to provide a descriptive foundation on which future evaluation and assessment of amnesty laws can be based. This mapping can provide data that is geographical in the sense that it reveals trends in amnesty law enactment within countries and across continents. However, it can also seek to describe the terrain and contours of amnesty laws themselves, in both their internal characteristics and external boundaries. To do this, as will be explored below, rather than treating amnesty laws as a homogenous group, the ALD breaks down individual amnesty laws into constituent elements, which are then classified and systematically analysed in order to identify patterns, correlations and anomalies in the different characteristics of these laws. As this chapter will explore below, this more fine-grained analysis is useful inter alia when determining whether amnesty laws are evolving in response to the justice cascade, as it reveals the extent to which contemporary amnesty laws grant or withhold amnesty for serious human rights violations.

\section{DEFINING AMNESTIES}

For all large-N comparative studies of amnesty laws, a central challenge is to define the concept of amnesty laws and then develop an operational definition of this concept. As has been noted for other transitional justice mechanisms, ${ }^{34}$ there is a lack of conceptual clarity on

\footnotetext{
${ }^{34}$ See eg Geoff Dancy et al, "The Turn to Truth: Trends in Truth Commission Experimentation," Journal of Human Rights 9, no. 1 (2010): 45-64.
} 
the nature of amnesty laws. This arises for several reasons. Firstly, within national legal systems, the term 'amnesty' may be defined differently and different bodies may be empowered to grant amnesties. ${ }^{35}$ Secondly, as amnesty laws have traditionally fallen within the domain of state sovereignty, no accepted international definition has developed. As a result of these conditions, the scope and legal effects of amnesty laws around the world can look very different, ranging from amnesty laws that aim to provide a form of reparations to persons who have been arbitrarily detained by a repressive state to self-amnesty laws enacted by dictatorial rulers or war criminals eager to avoid penal sanctions. Indeed, Mark Freeman has suggested that "the difference between certain amnesties is so vast ... that it is almost nonsensical to compare them'. ${ }^{36}$

Developing a clear definition of amnesty is further complicated as, although international law seeks to differentiate between amnesties and other leniency measures such as pardons and use immunity, domestic law can blur these distinctions. For example, the American Constitution empowers the President 'to grant Reprieves and Pardons for Offenses against the United States, except in Cases of Impeachment', ${ }^{37}$ but makes no explicit reference to amnesties. However, in practice, the US Supreme Court has interpreted this provision to include the power to grant amnesties, ${ }^{38}$ and the Court has proclaimed that the president can exercise this power for both offenders who have been convicted and for persons who have yet to be investigated or stand trial. ${ }^{39}$ In addition, many amnesty laws seek to distinguish between categories of offenders with the result that one law may offer a range of different forms of

\footnotetext{
${ }^{35}$ See eg René Lévy, "Pardons and Amnesties as Policy Instruments in Contemporary France," Crime and Justice 36 (2007): 551.

${ }^{36}$ Freeman, Necessary Evils 13.

${ }^{37}$ U.S. Constitution, art. II, § 2.I

${ }^{38}$ United States v. Klein, 80 U.S. 128, 147 (1871).

${ }^{39}$ Ex Parte Garland, 71 U.S. 333 (1866).
} 
leniency, such as amnesty, probation and sentence reductions, which are allocated to distinct categories of offenders. ${ }^{40}$

To accommodate these conceptual difficulties, the Amnesty Law Database has taken a broad, inclusive approach. Unlike quantitative databases, which before beginning to collect and code data, develop tightly defined and measureable definitions of amnesties that are drawn deductively from theoretical literature, the Amnesty Law Database takes a more inductive, grounded approach. As a result, a working definition was initially drawn from the theoretical and legal literature on amnesties, but during the process of data collection, this definition was developed and redefined in response to the identification of common features of amnesty laws. This process has resulted in the adoption of operational definition, which requires that in order to be included in the database, an amnesty process must be:

- A de jure measure ${ }^{41}$

- Enacted by state authorities ${ }^{42}$ through promulgated laws, peace agreements or executive policies $^{43}$

- Related to political offences (this can range from non-violent dissident activities to the perpetration of crimes under international law) ${ }^{44}$

- Designed to remove criminal and/or civil sanctions - this primarily entails amnesties that apply pre-conviction, but post-conviction measures are included where (1) they are

\footnotetext{
${ }^{40}$ See eg Loi Relative Au Rétablissement De La Concorde Civile, Loi no 98-08, (1999).

${ }^{41}$ ALD does not contain data on 'de facto amnesties', a term that describes failures to prosecute for whatever reason, rather than enacted policies to prevent prosecution.

${ }^{42}$ ALD excludes amnesties proclaimed by non-state actors.

${ }^{43}$ The inclusion of executive policies means that for some amnesty processes, no formal law was enacted.

${ }^{44}$ ALD excludes amnesties that are granted for common crimes or for economic crimes (eg the National Reconciliation Ordinance 2007, Pakistan).
} 
granted in conjunction with pre-conviction amnesties; or (2) they eliminate not just the penalty, but also the criminal record for political prisoners

- Formally implemented and/or taken advantage of by some of the targeted individuals

As a result of this broad definition, within the Amnesty Law Database, there is great disparity in the types of amnesties included. However, as each of these amnesties is then broken down into distinct categories, this can enable researchers to develop more narrowly focused comparisons by, for example, looking only at amnesties granted for members of non-state armed groups or only at amnesties for crimes under international law.

\section{DATABASE DESIGN: TABLES AND VARIABLES}

As the Amnesty Law Database was intended primarily to describe amnesty processes, it was not created using spreadsheets or statistical software. Instead, the database was developed using relational tables in Microsoft Access as this facilitated the inclusion of extensive descriptive text, rather than coded data, although the database does nonetheless facilitate some limited counting to identify patterns. In the initial design phase, key issues relating to the causes, scope and legal effects of amnesty laws were identified from the theoretical literature, an initial survey of amnesty legislation and national and international case law. These issues included why and how the amnesty was introduced, what crimes it covered, who benefited from the amnesty, whether conditions were attached, what legal effects the amnesty had, how the amnesty was implemented, how it related to other transitional justice mechanisms, and how courts and other stakeholders responded to the amnesty process. The relational tables in the database correspond to these issues.

After the relational tables had been identified, each of these issues was broken down into specific variables based deductively upon the international legal standards and on issues that arose from the secondary analyses of amnesties, and inductively from frequently 
occurring elements within amnesty legislation. For example, the table relating to the crimes covered by the amnesty contained variables on whether crimes under international law, political crimes, economic crimes or other crimes against individuals were included or excluded from the amnesty. ${ }^{45}$ It also included variables on whether there were temporal or geographic restrictions relating to the commission of these crimes. For each of these variables, where appropriate, the database contains text detailing the scope of the amnesty law drawn from the law itself and other sources. Only a small sample of this data will be explored here, as the majority of the variables are beyond the scope of this chapter.

Once the data has been compiled for a number of amnesty processes, the database is used to identify patterns by running queries to view the total number of amnesties with data for a particular variable, to examine patterns for a particular variable over time or across regions, and to identify relationships between different variables, such as whether amnesties for crimes under international law are more likely to be granted to non-state actors. In addition, by entering the descriptive text, rather than numerical codes for each variable, the exact provision of the amnesty law can be easily retrieved.

\section{DATA COLLECTION: CONTEXTS, SCOPE AND SOURCES}

Following the model outlined in the 1985 Joinet report, the Amnesty Law Database does not restrict itself solely to amnesties enacted during political transitions, but rather gathers data on amnesties emanating from all forms of political crises including civil unrest, military coups, international or internal conflict, authoritarian government, or states that are transitioning from such crises. Pursuing this broader approach is significant for several reasons. Firstly, it includes analyses of amnesty laws introduced in contexts where crimes

\footnotetext{
${ }^{45}$ Data is only collected on amnesties for economic crimes or common crimes where they are part of a broader amnesty for political offences.
} 
under international law may not have been committed, or where the amnesty laws are designed to remedy human rights violations, such as arbitrary detention or forced displacement, rather than promote impunity. By including these forms of amnesties, the research can cast light on how amnesty laws can be used in ways which do not conflict with international law. Secondly, in many transitional contexts, questions of whether international crimes were committed are often highly contested. For example, in Northern Ireland during the Troubles, the British government resisted efforts to characterise the violence as a conflict, which would fall under the international humanitarian law framework, and instead preferred to apply domestic criminal law. By extending the scope of the database beyond situations in which international crimes have been widely recognised to have been committed, the Amnesty Law Database can incorporate such contested contexts. Thirdly, by including amnesty laws introduced in 'pre-transition' periods, the database can capture information on amnesties that are used as counter-insurgency tools or to facilitate peace negotiations. Although such contexts are not strictly speaking 'transitions', where amnesties are granted prior to a transition, they can influence the choice of transitional justice policies adopted by constraining the extent of accountability that can be pursued.

Although political amnesties have been used for millennia, the temporal scope of the Amnesty Law Database is restricted to amnesties that were introduced after the end of the Second World War. This cut-off date was selected as it was from 1945 that international human rights law and international criminal law began to develop. For amnesties occurring after this date, the database, rather than sampling, includes all amnesty laws that meet the operational definition outlined above. ${ }^{46}$

\footnotetext{
${ }^{46}$ However, due to the difficulties in identifying and compiling information on amnesty laws, it will be impossible to determine whether the database will ever provide a fully comprehensive survey of amnesty laws for this period.
} 
In compiling data on individual amnesty processes, a range of documentary sources were employed including domestic legislation; international treaties and peace agreements; scholarly writings; jurisprudence from national and international courts and opinions given by treaty-monitoring bodies; statements and reports by intergovernmental organisations (particularly the UN institutions); reports by states (particularly Country Reports on Human Rights Practices from the US Department of State); reports by NGOs (particularly Amnesty International, Human Rights Watch and International Crisis Group); and newspaper articles. ${ }^{47}$ Challenges to data collection were similar to those faced by other comparative social science scholars, and included language difficulties, the time that had elapsed since the amnesty was introduced, the lack of transparency in the state concerned, bias within the available sources, or a relative lack of academic research on the relevant transitional state. To try to combat these problems, as well as often obfuscatory language within amnesty laws, efforts were made to base the description of each amnesty on as wide a variety of sources as possible.

At the time of writing, the Amnesty Law Database contains information on 537 amnesty laws in 129 countries that were introduced between 1945 and June 2011. As the start of the justice cascade or the global accountability norm is commonly dated to the late 1970s, this chapter will limit its analysis to amnesties introduced between 1979 and 2011. This means that global and regional trends will be explored for a total of 398 amnesties laws enacted in 115 countries.

\footnotetext{
${ }^{47}$ For each amnesty profile in the database, the range of sources used to compile the information is listed at the end of the profile.
} 


\section{GLOBAL AND REGIONAL TRENDS IN AMNESTY ADOPTION, 1979-2011}

With the expansion of international criminal law and transitional justice, scholars and practitioners have frequently proclaimed 'the impending demise of amnesty'. ${ }^{48}$ This section will explore whether these assertions are premature by analysing global and regional trends in amnesty adoption over the past thirty years. In particular, it will assess whether the growth of the 'justice cascade' has contributed to a fall in the number of amnesty laws enacted for crimes under international law.

\section{Amnesty Trends by Year}

In the midst of the Cold War, many countries experienced dictatorship or conflict. For example, according to Freedom House, 41 per cent of the world's countries were 'not free' and a further 31 per cent were only 'partially free' in $1978 .{ }^{49}$ In addition, the Uppsala Conflict Data Program has found that the number of active conflicts around the world increased during the $1970 \mathrm{~s} .{ }^{50}$ As a result of these dynamics, the number of amnesty laws also increased sharply during that decade. ${ }^{51}$ As the focus of this chapter is on the period from 1979 , the global trend in the enactment of political amnesties in each of the following years is shown in Figure 1:

\footnotetext{
${ }^{48}$ See eg Lisa Laplante, "Outlawing Amnesty: The Return of Criminal Justice in Transitional Justice Schemes," Virginia Journal of International Law 49, no. 4 (2009): 932.

${ }^{49}$ Freedom House, 'Freedom in the World Country Ratings' available online at http://www.freedomhouse.org/uploads/fiw09/CompHistData/CountryStatus\&RatingsOverview1973-2009.pdf (accessed 11 July 2011).

${ }^{50}$ Uppsala Conflict Data Program, ‘Active Conflicts by Region', available online at http://www.pcr.uu.se/research/UCDP/graphs/conflict_region_2008.pdf (accessed 26 July 2011).

${ }^{51}$ See Mallinder, Amnesty, Human Rights and Political Transitions 19.
} 


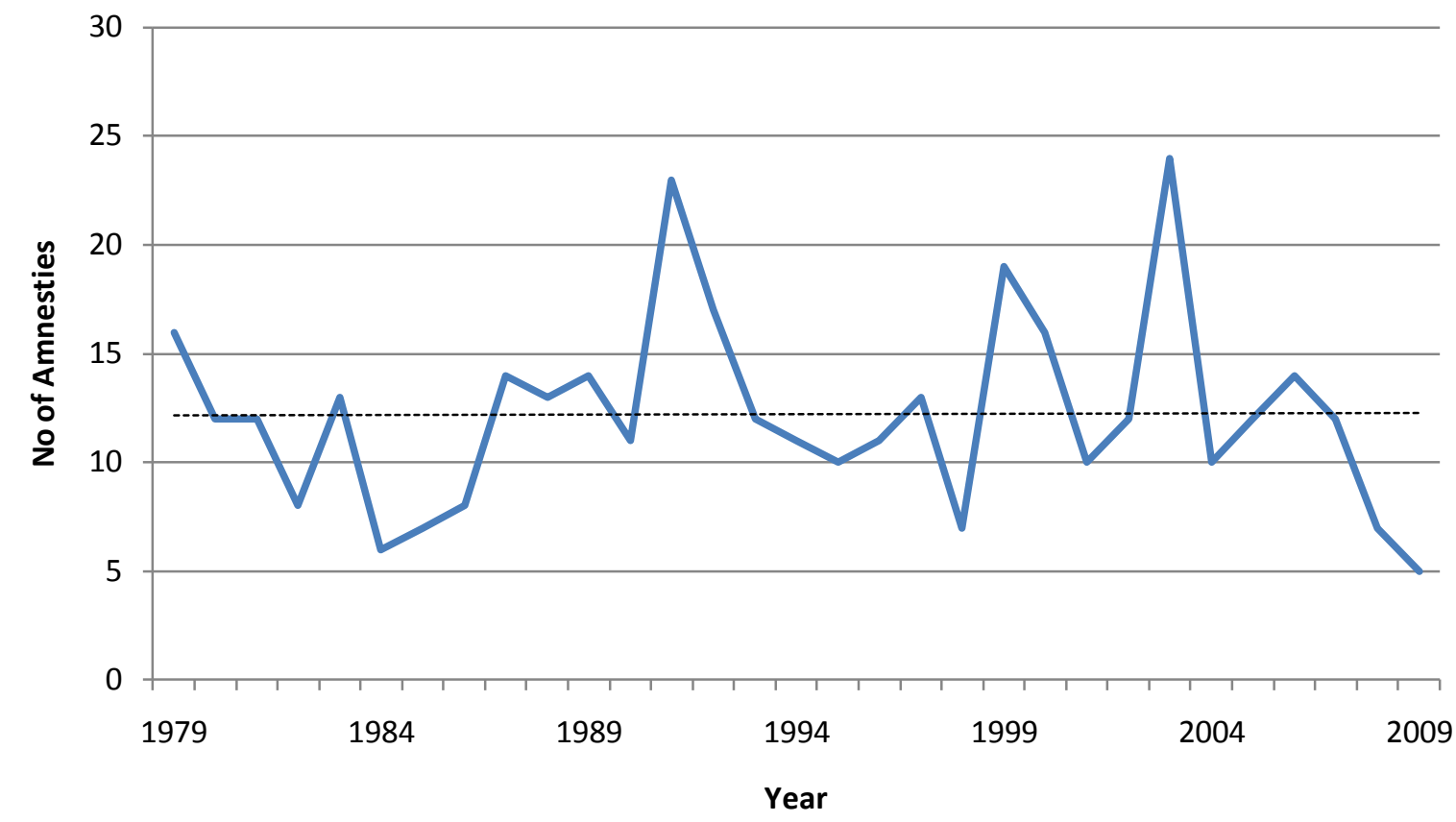

Figure 1: Global number of amnesties enacted by year (1979-2010).

Between January 1979 and December 2010, an average of 12.25 amnesty laws were enacted each year, and between January to June 2011 a further six amnesties have been introduced. However, as Figure 1 illustrates, between 1979 and 2010, the global rate of amnesty law enactment went through a number of peaks and troughs. For example, following the end of the Cold War in 1989, the number of amnesty laws rose sharply. This increase can be attributed to firstly, the political transitions that took place in the former communist states in Eastern Europe, which resulted in a series of amnesty laws, predominantly to benefit dissidents whose actions had been criminalised by the former regimes. The end of the Cold War also meant that the superpowers stopped propping up dictatorial regimes or intervening in civil wars to prolong the violence. The end of these interventions meant that many countries moved towards negotiated peace agreements or pacted transitions that often included amnesties. Conversely, the collapse of the Soviet Union and the former Yugoslavia caused some newly independent states to spiral into civil war as ethnic tensions that had previously been suppressed came to the fore. These conflicts contributed to a series of 
amnesties in the late 1990s. The impact of the end of the Cold War on amnesty rates has been noted by other comparative studies. For example, in 2005 Binningsbø et al wrote that 'the probability of amnesty after the Cold War is ... higher than the probability that a conflict was followed by amnesty in the decades after the Second World War'. ${ }^{52}$ Although the frequency with which amnesties were enacted varied considerably during these three decades, the global trend, as shown by the dotted line, indicates that the rate of amnesty laws introduced has remained constant. This trend has also been found by Olsen et al, who argue that their Transitional Justice Data Base illustrates 'a steady persistence of amnesties'. ${ }^{53}$ Similarly, Mark Freeman has argued that 'amnesties are as prevalent today as at any time in modern history ... we are no more at the end of amnesties than we are at the "end of history". 54

The past decade has seen many developments in international criminal law, including the creation of the ICC, universal jurisdiction proceedings for human rights violations in several countries, and the UN's decision from 1999 to refrain from recognising amnesty laws for serious crimes under international law. The expectation among human rights campaigners has been that these developments would make amnesty laws less attractive for perpetrators and would gradually lead to a reduction in their use. To explore whether such a decline has begun to develop, Figure 2 isolates global trends in amnesty enactment from 1 January 1999:

\footnotetext{
${ }^{52}$ Helga Malmin Binningsbø et al, "Civil War and Transitional Justice, 1946-2003: A Dataset” (paper prepared for presentation at the 'Transitional Justice and Civil War Settlements' workshop in Bogotá, Colombia 18-19 October 2005) 17-18.

${ }^{53}$ Olsen, Payne and Reiter, Transitional Justice in Balance.

${ }^{54}$ Freeman, Necessary Evils 4.
} 


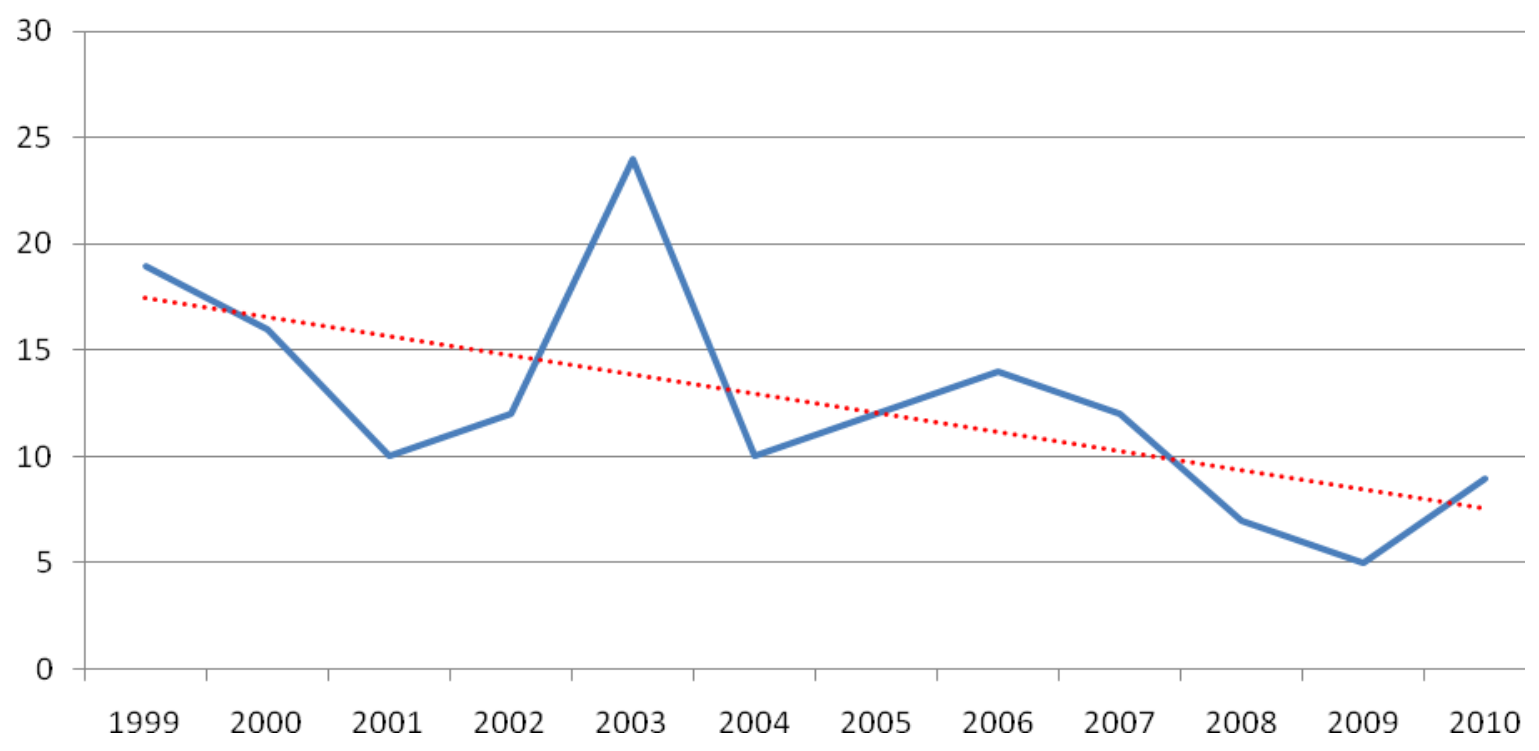

Figure 2: Global amnesty enactment trends, January 1999 - December 2010.

From January 1999 to December 2010, an average of 12.5 amnesty laws were enacted annually, but as with the longer time period, Figure 2 indicates that over the past decade there has been considerable variation in the total number of amnesties introduced each year. For example, in 2003, the year following the creation of the ICC, the number of amnesty laws enacted was almost double the average annual enactment rate, and amounted to the largest annual total to have been enacted in any year. During 2003, amnesty laws were enacted in every region of the world, although to differing frequencies, ${ }^{55}$ and in diverse political contexts. ${ }^{56}$ In contrast to 2003 , in 2009 only half the annual average of new amnesty laws were enacted. Overall, however, although the average number of amnesty laws enacted annually since 1999 is slightly higher than for 1979-2010, the global trend as illustrated by the dotted lines indicates a fall in the rate of amnesty enactment since 1999. As the rate of amnesty law enactment frequently goes through sizeable peaks and troughs, it is too early to

\footnotetext{
${ }^{55}$ Eg over a third of the total was enacted within Sub-Saharan Africa, whereas only one was enacted in the Americas.

${ }^{56} \mathrm{Eg} 35$ per cent emanating from repressive regimes and 43 per cent from ongoing conflicts or transitions from conflict.
} 
determine whether this reflects an emerging trend in state practice, or whether it is just a temporary fall in the numbers. Indeed, from January 2010, the number of amnesty laws being introduced seems to be climbing again, a change which in 2011 can be partially attributed to the amnesties proclaimed in the 'Arab Spring'. It seems therefore that caution is warranted when looking at these contemporary trends, particularly since the rates of change have not occurred uniformly across all regions.

\section{Amnesty Laws by Region}

Within the Amnesty Law Database, countries are allocated to one of the five following regions: Americas, Asia, Europe and Central Asia, Middle East and North Africa, and SubSaharan Africa. As shown in Figure 3, amnesties were enacted in all regions of the world since 1979:

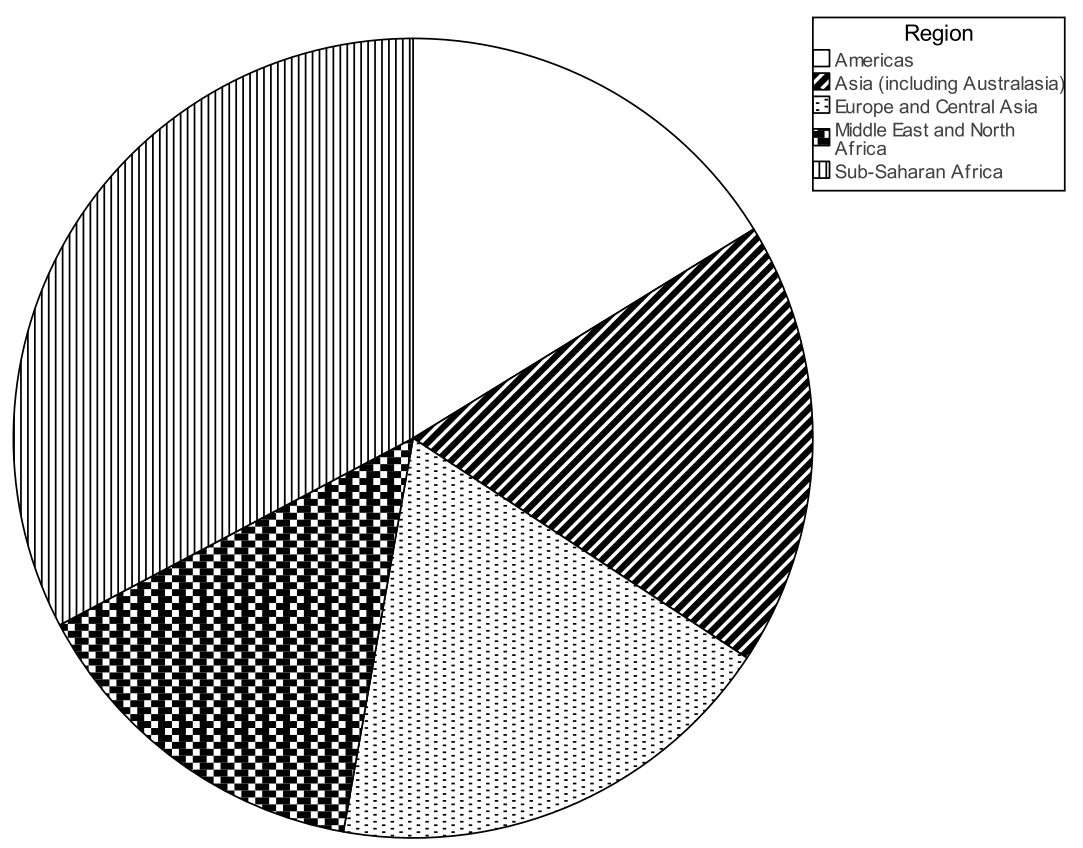

Figure 3: Amnesty laws by region, 1979-2010.

It is perhaps unsurprising that the greatest proportion of amnesty laws enacted from 1979 to 2010 was introduced in Sub-Saharan Africa (33 per cent) due to that region's large number of 
states and high incidence of conflict. ${ }^{57}$ However, it is quite striking that there is very little difference between the proportions of amnesty laws enacted in the Americas (16 per cent), Asia (18 per cent) and Europe and Central Asia (19 per cent) during this period. This is particularly remarkable, as Europe and the Americas have more developed regional human rights monitoring mechanisms than Asia. However, among these regions there are considerable variations over time, as shown in Figure 4:

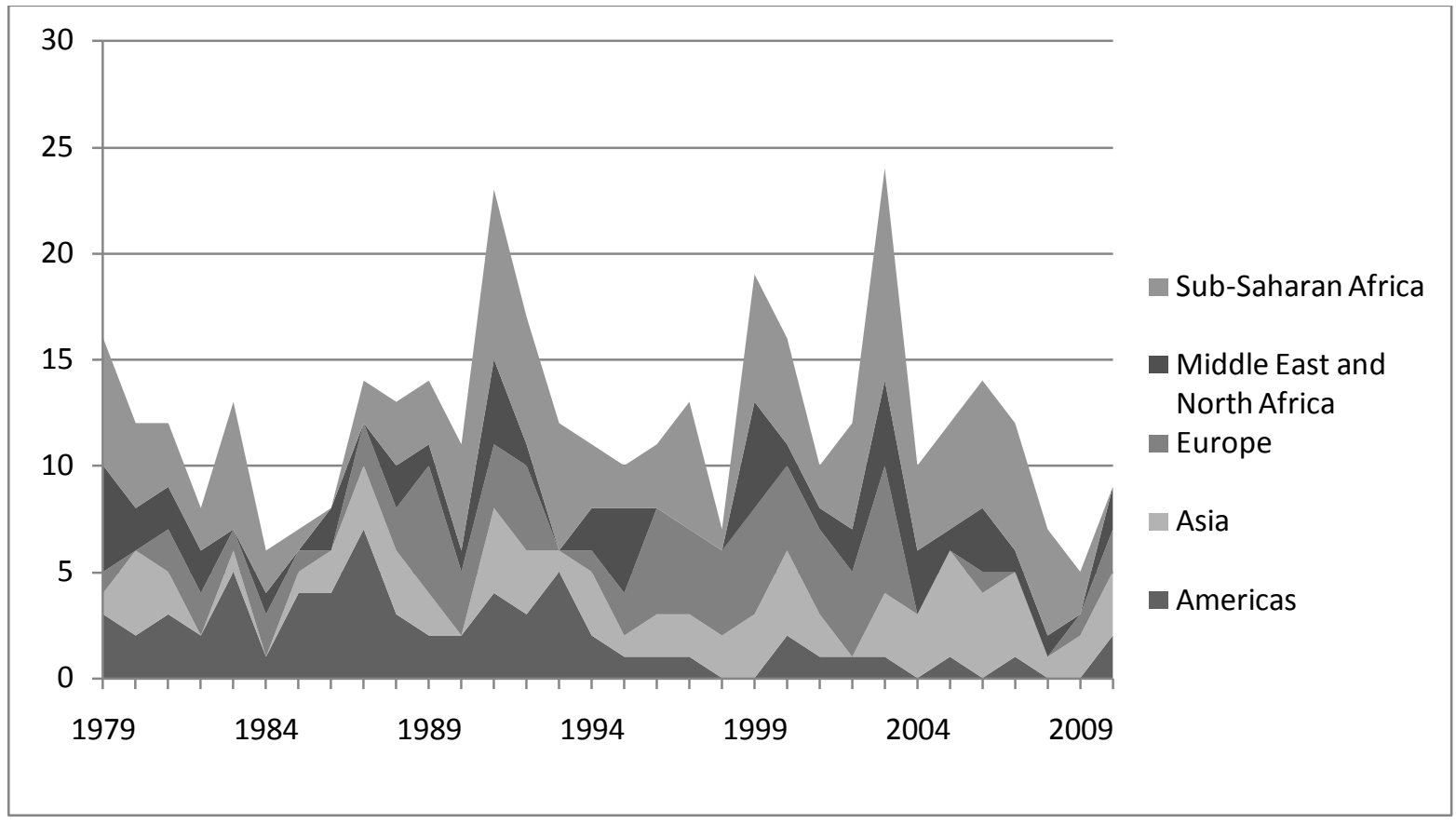

Figure 4: Regional trends by year, 1979-2011.

By looking at the regional trends over time, some interesting patterns emerge. For example, during the 1980s, the Americas had the highest rate of amnesty law enactment, which can be attributed to the military dictatorships and civil wars that occurred in the region during this decade. However, the region's rate of amnesty enactment declined sharply from the mid1990s from which point it has had the lowest rate of new amnesty laws being introduced (although most of its pre-existing amnesty laws have remained in effect). The overall trend

\footnotetext{
${ }^{57}$ Uppsala Conflict Data Program, ‘Active Conflicts by Region', available online at http://www.pcr.uu.se/research/UCDP/graphs/conflict_region_2008.pdf (accessed 26 July 2011).
} 
for the Americas between 1979 and 2010 is one of declining numbers of new amnesty laws. This finding reflects the changing political conditions in the region since the late 1980s, particularly the establishment of democratic government in many countries. ${ }^{58}$ The rate of amnesty law enactment in the Middle East and North Africa remained constant. However, four amnesties have been introduced in this region between January and June 2011, which could mark the start of a change in this trend, particularly since the rate of amnesties in this region has historically been low. ${ }^{59}$ In contrast, the amnesty trends for the remaining three regions showed an increased reliance on new amnesties between 1979 and 2010. The sharpest increase in the rate of amnesty law enactment occurred in Asia, although the numbers of new amnesties in this region remain less than in Sub-Saharan Africa. If the regional trends are analysed for the years from 1999 to 2010 , unsurprisingly given the global trends for the decade, an increasing number of regions have witnessed declining amnesty law enactment rates. Asia remains the only region where the rate of new amnesty law enactment has remained constant, whilst Europe and Central Asia has witnessed the steepest decline. The constant rate in Asia could perhaps reflect that during the past decade, this region has had the highest rates of ongoing conflict. ${ }^{60}$ The impact of the different political crises on the rates of amnesty law introduction will be explored below.

\section{Amnesty Laws by Political Crises}

As noted above, the Amnesty Law Database compiles data on amnesty laws introduced in response to a range of political crises. Within the database, these crises have been broken

\footnotetext{
${ }^{58}$ Sikkink and Walling, The Impact of Human Rights Trials in Latin America.

${ }^{59}$ Between 1979 and 2010, only 53 amnesties were introduced in the Middle East and North Africa, which gives an average of 1.65 amnesty laws per year.

${ }^{60}$ Uppsala Conflict Data Program, ‘Active Conflicts by Region', available online at http://www.pcr.uu.se/research/UCDP/graphs/conflict_region_2008.pdf (accessed 26 July 2011).
} 
down into seven fields: ${ }^{61}$ conflicted democracy, ${ }^{62}$ coup attempt, ongoing conflict, ongoing repression, transition from dictatorship, transition from internal conflict, and transition from international conflict. ${ }^{63}$ The distribution for each of these transition types for the years from 1979-2011 can be seen in Figure 5:

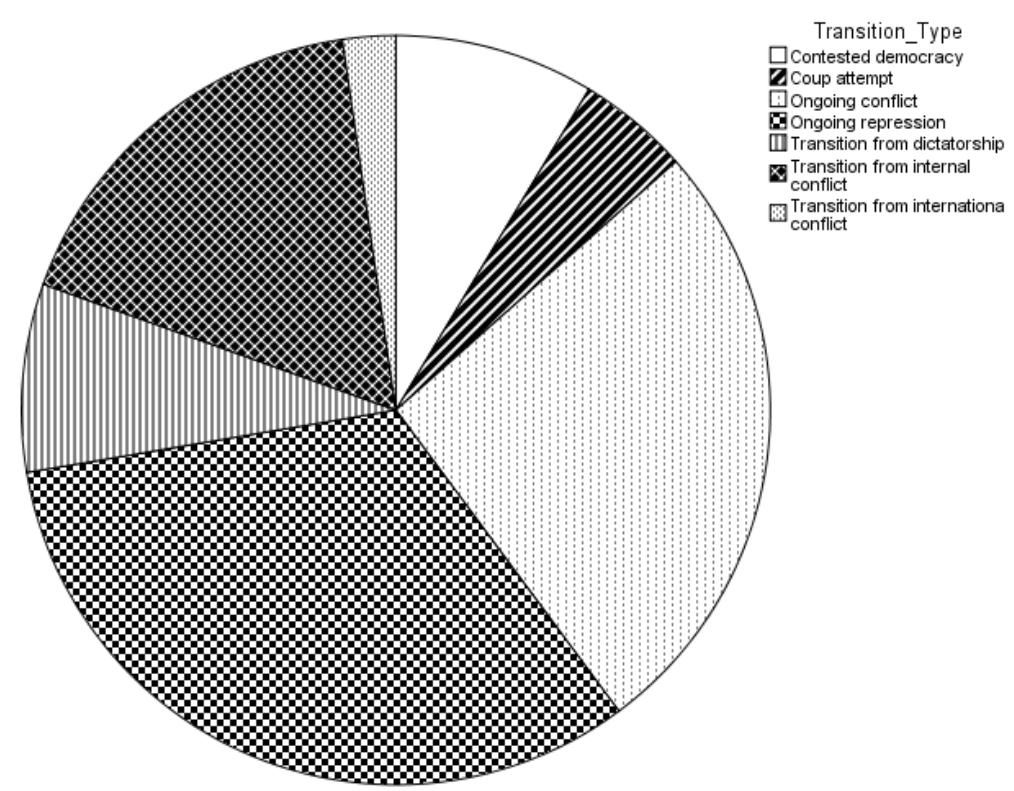

Figure 5: Amnesty laws by transition type, 1979-2011.

${ }^{61}$ There is overlap between some of these categories, for example, a country could be in transition from dictatorship, but the military could still exercise considerable influence resulting in some policies of repression. Furthermore, distinguishing between internal and international conflicts can be problematic. In addition, these categorisations simplify what in many states could be multiple transitions, for example, both from conflict to peace, but also from authoritarian rule to democracy. Finally, the transitions are classified according to the moment when the amnesty was introduced. For example, the term "transition from conflict" is used if elections have been held or peace agreement signed, even where violence later reignites.

${ }^{62}$ Within this study, conflicted democracy denotes various contexts including widespread anti-government protests, violence erupting from elections, or terrorist violence within democratic states. See Fionnuala Ní Aoláin and Colm Campbell, "The Paradox of Transition in Conflicted Democracies," Human Rights Quarterly 27, no. 1 (2005): 172-213.

${ }^{63}$ As noted above, this is a much broader range of contexts than are included in other datasets on amnesty laws, that focus solely on amnesties enacted as part of a transition or negotiated peace agreements. 
This chart illustrates that over the past thirty years almost half of all amnesties enacted were related to conflicts, either when the conflict was ongoing or during peace negotiations. If the data is restricted to the years from 1999 to 2011, the proportion of amnesties related to conflict rises to slightly over 50 per cent. As noted above, the relationship of amnesties to conflict resolution has been explored in comparative large- $\mathrm{N}$ studies on peace agreements, which have found that peace accords are more likely to include amnesty laws than other forms of transitional justice. For example, in a survey of peace agreements made between 1980 and 2006, Vinjamuri and Boesenecker found that whilst 'provisions for prosecutions and truth commissions are rare in peace agreements, ... the use of amnesty is comparatively common'. ${ }^{64}$ They further found that the rates of amnesties in the agreements remained 'relatively stable over the time period analysed', ${ }^{65}$ even though from 2000 , the number of peace agreements concluded declined. ${ }^{66}$ Among the amnesty provisions identified by Vinjamuri and Boesenecker, they found that 21 per cent of the agreements contained 'no justice mechanism, amnesty provision, or IHL/HR law reference whatsoever'. ${ }^{67}$ This finding has been interpreted by the Center for Humanitarian Dialogue as illustrating that the most active proponents and perpetrators of war are relatively unchallenged by law in most peace agreements. When justice mechanisms are adopted, the overwhelming trend is towards strategies of co-existence, forgiveness and reconciliation instead of legal accountability. ${ }^{68}$

\footnotetext{
${ }^{64}$ Vinjamuri and Boesenecker, Accountability and Peace Agreements 5.

${ }^{65}$ Ibid. 9.

${ }^{66}$ Ibid. 13.

${ }^{67}$ Ibid. 9.

${ }^{68}$ Centre for Humanitarian Dialogue, 'Charting the roads to peace: Facts, figures and trends in conflict resolution', Mediation Data Trends Report (Centre for Humanitarian Dialogue, Geneva 2007) 15.
} 
The prevalence of amnesty laws in peace agreements is perhaps a reflection that within much of the literature, amnesties introduced to bring mass violence to an end are viewed as more acceptable than self-amnesties introduced by dictatorial rulers or amnesties enacted by democratic politicians some time after a transfer of power. The role of amnesty in facilitating the peaceful resolution of violent conflict has been recognised by states parties to the Additional Protocol II to the Geneva Conventions. This is the only treaty to mention amnesty laws explicitly and it encourages states parties to enact the 'broadest possible amnesty to persons who have participated' in non-international armed conflicts. ${ }^{69}$

In addition to conflict-related amnesties, 40 per cent of amnesties resulted from dictatorial rule, either introduced by the repressive regime itself (38 per cent) or by its successors ( 8 per cent). As noted above, the number of repressive regimes in the world has declined since 1979 and consequently the number of amnesties that result from such contexts has declined over the past three decades.

If these global trends on political crisis are analysed by region considerable divergences are apparent, as illustrated in Figure 6:

\footnotetext{
${ }^{69}$ Protocol Additional to the Geneva Conventions of 12 August 1949, and relating to the Protection of Victims of Non-International Armed Conflicts (Protocol II) 1977, Art 6(5).
} 


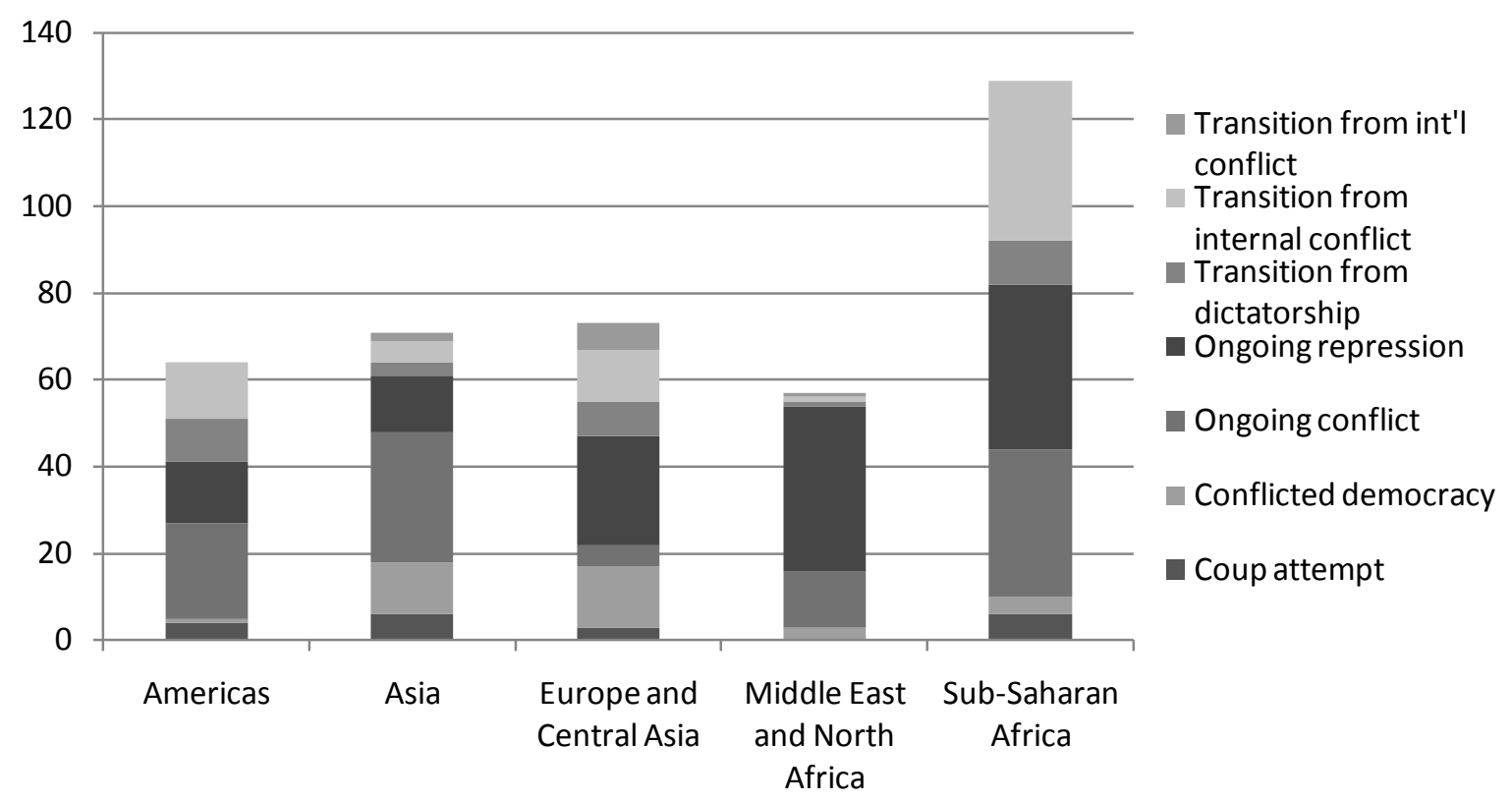

Figure 6: Regional trends by political crisis, 1979-2011.

This chart illustrates that, during the past thirty years, amnesties resulting from ongoing conflicts featured most heavily in Sub-Saharan Africa, followed by Asia and the Americas. If the data is analysed just for the past decade, ongoing conflicts remain a significant factor in both Africa and Asia, and in particular, amnesties as part of transitions from internal conflict are most prevalent in Sub-Saharan Africa. In contrast, since 1979 amnesties relating to dictatorial regimes were introduced most often in the Middle East and North Africa. Despite the differences in the type of political crisis that can trigger the enactment of amnesty laws, in many of these contexts, serious human rights violations were committed by both government forces and non-state actors.

\section{Amnesties and Crimes under International Law}

Unlike other datasets that focus only on amnesty laws for human rights abuses, as noted above, the Amnesty Law Database includes amnesties enacted for a wide range of political offences. As a result, serious human abuses are not a factor for all amnesties in the Amnesty Law Database. Furthermore, due to the differences in states' ratifications of human rights 
treaties and the existence of human rights institutions in different regions, the Amnesty Law Database does not focus on gathering data on human rights abuses broadly defined. Instead, it isolates only amnesties for international crimes, namely, genocide, war crimes, crimes against humanity, disappearances and torture. Where the text of amnesty laws does not explicitly state which crimes are included or excluded in an amnesty, determining whether international crimes are a factor is problematic, particularly when states for political reasons decline to acknowledge the inclusion of international crimes in the amnesty legislation, preferring instead to frame them as domestic crimes. In addition, some individual amnesty processes both include and exclude crimes under international law, by for example, excluding crimes against humanity from the amnesty, but allowing torturers to escape prosecution. In constructing the Amnesty Law Database, the author has taken a cautious approach and entered data relating to international crimes only when (1) the following crimes were explicitly mentioned in the text of the amnesty: war crimes, genocide, crimes against humanity, torture and disappearances; (2) when case law indicated that the amnesty included or excluded these crimes; and/or (3) when there is substantial evidence in reports by $\mathrm{UN}$ or regional human rights institutions or by respected human rights organisations, such as Amnesty International or Human Rights Watch, that crimes under international law were perpetrated. As a result, it is probable that the Amnesty Law Database under-represents the number of amnesty processes which grant impunity for crimes under international law. Nonetheless, Figure 7 illustrates trends in the relationship between amnesties and international crimes: 


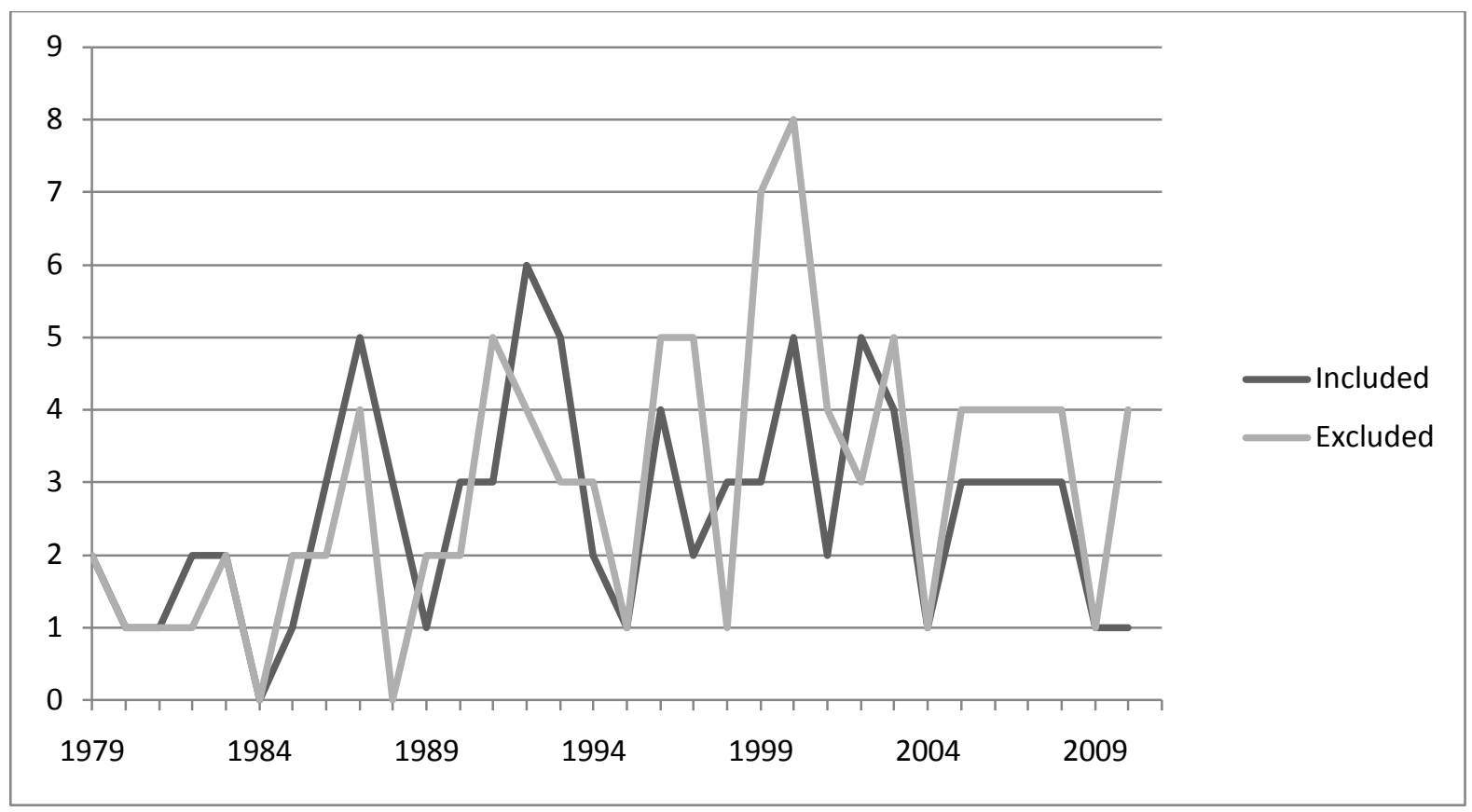

Figure 7: Trends in amnesties and international crimes by year, 1979-2010.

The trends illustrated in Figure 7 relate only to amnesty laws in which it has been clearly identified that crimes under international law have been included or excluded. When the patterns are looked at over the past thirty years, it becomes apparent that both approaches have been a feature of amnesty laws around the world. The rates of amnesties including crimes under international law has increased over the past thirty years, but for most years since the early 1990s, more amnesties have excluded crimes under international law. However, it is interesting to note that after a peak around 1999, the number of amnesties explicitly excluding crimes under international law has fallen.

The past decade is perhaps the most significant period in the relationship between crimes under international law and amnesties due to the creation of the ICC and the change in the UN's stance towards amnesties for serious human rights violations. The yearly trends for this decade are illustrated in Figure 8: 


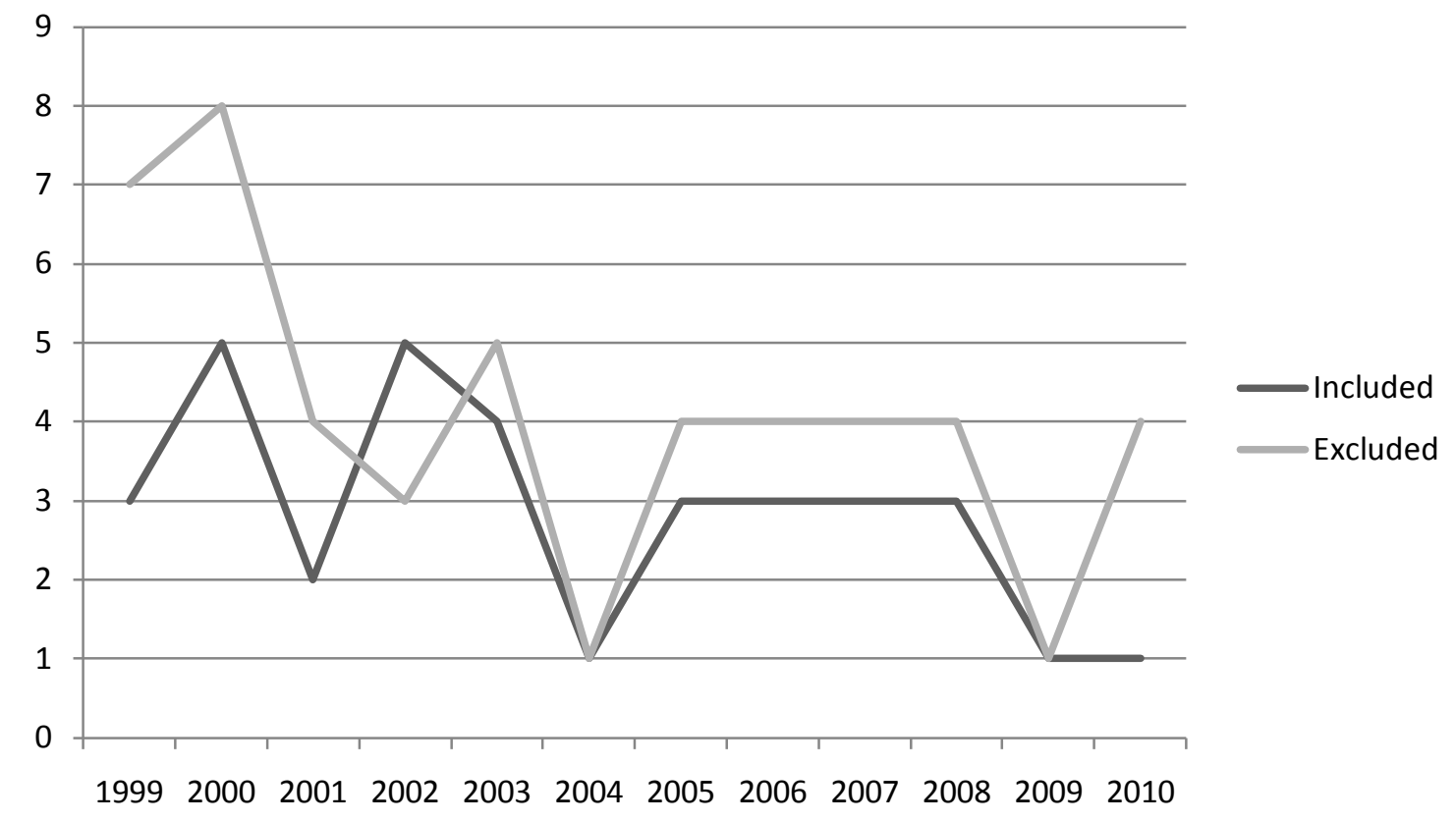

Figure 8: Trends in amnesties and international crimes, 1999-2010.

This chart shows that, as the rate of amnesty law enactment has fallen since 1999, the number of amnesties both including and excluding crimes under international law has also fallen. However, where states still chose to enact amnesty laws, this chart indicates that states are only slightly more likely to exclude serious human rights violations from the amnesty law than to include them.

During the period 1979-2010, there were regional differences in approaches to granting amnesties for crimes under international law as illustrated in Figure 9: 


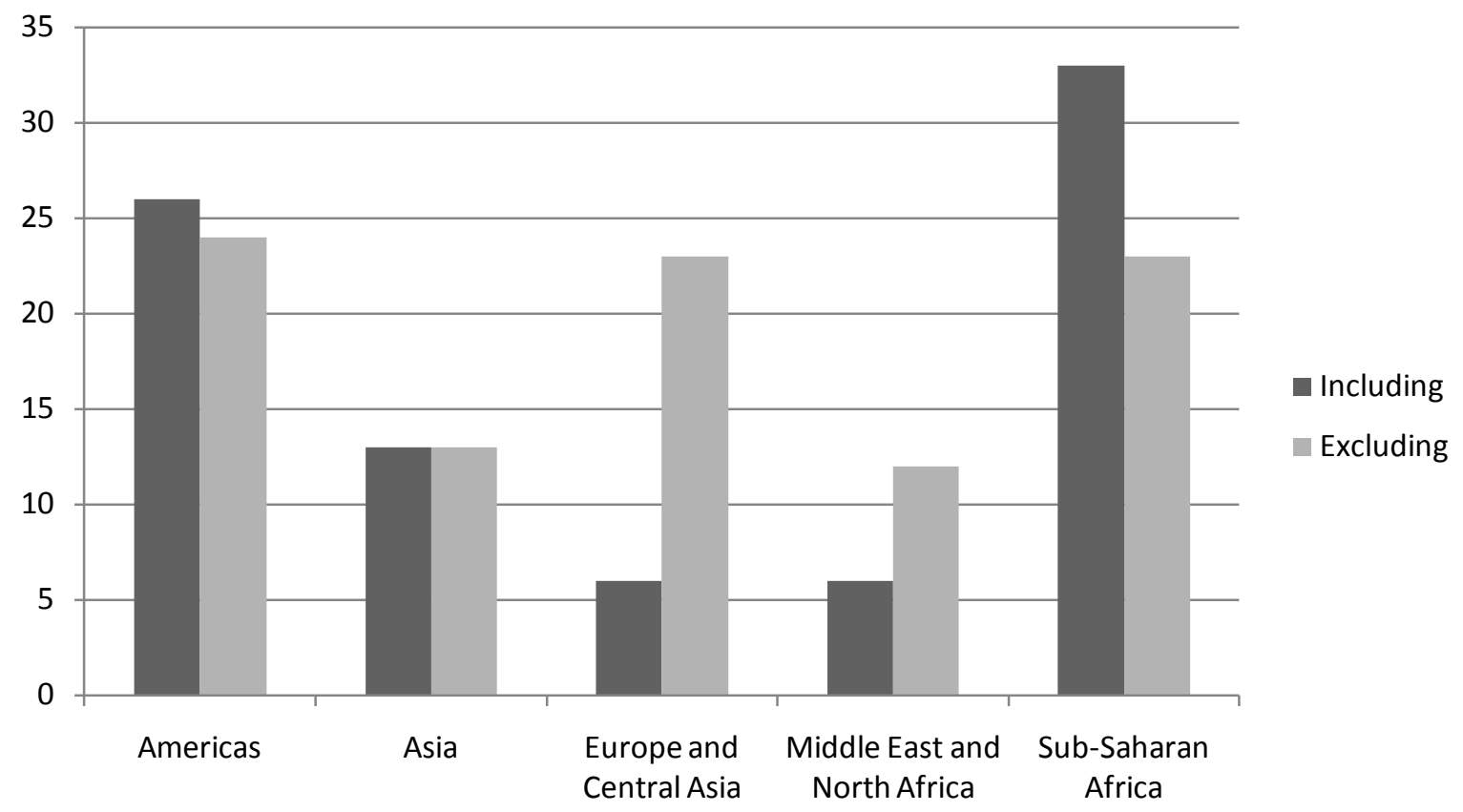

Figure 9: Amnesties and international crimes by region, 1979-2011.

From Figure 9, we can see that the only regions where the number of amnesties excluding crimes under international law exceeded the number of amnesties that included such crimes are Europe and Central Asia, and the Middle East and North Africa. In all other regions during the past thirty years, states have been more likely to amnesty crimes under international law than to exclude them. These trends have changed during the past decade, particularly in relation to the Americas, as shown in Figure 10: 


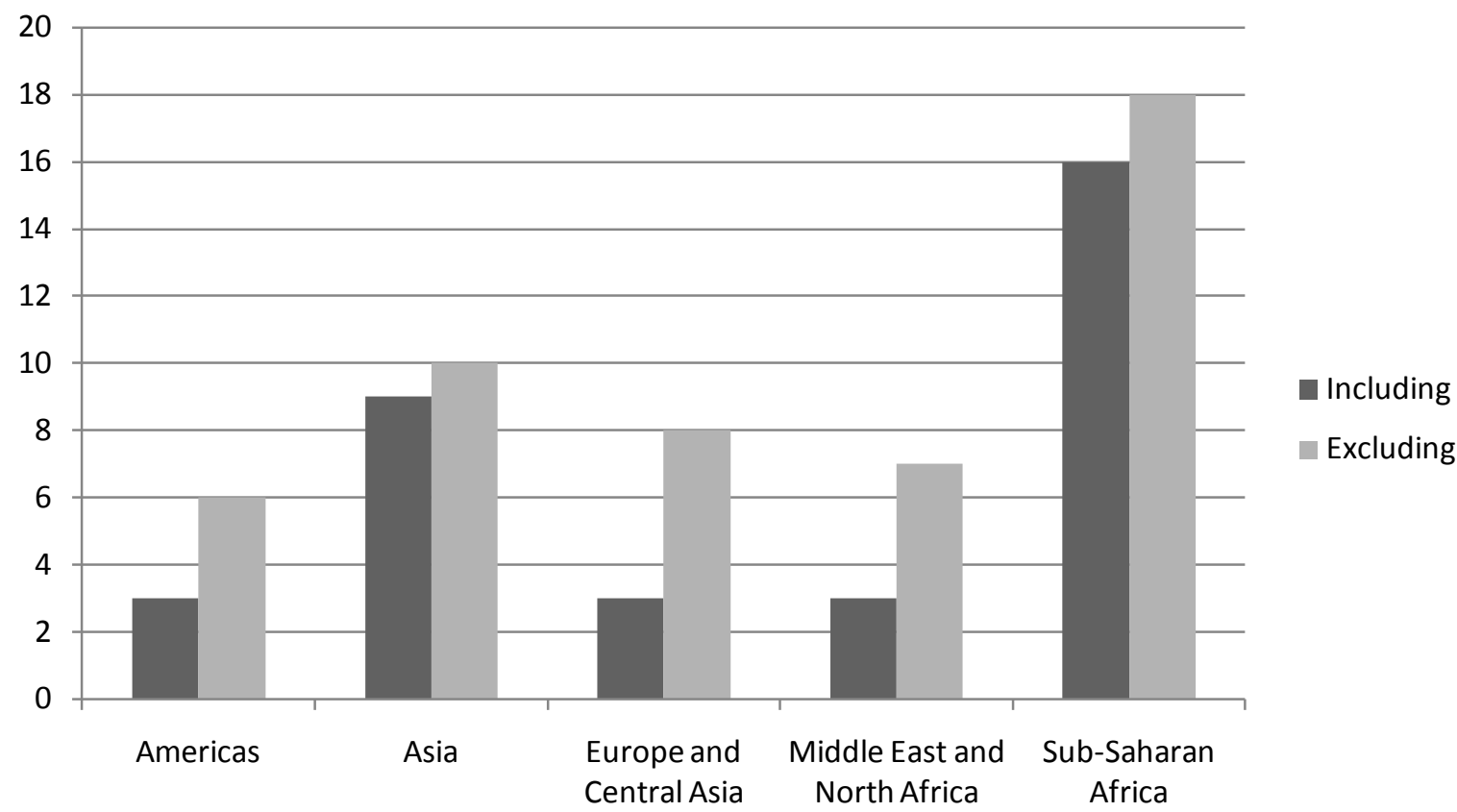

Figure 10: Amnesties and international crimes by region, 1999-2010.

From this chart, we can see that Europe and Central Asia is now the region least likely to grant new amnesties for crimes under international law. Furthermore, in all regions of the world in the past decade, the newly enacted amnesty laws have been more likely to exclude crimes under international law than to include them. However, in Asia and Sub-Saharan Africa, the likelihood is less pronounced.

This section has illustrated a range of trends relating to when, where and in what context, new amnesty laws have been enacted, and the extent to which these laws apply to crimes under international law. The implications of these global and regional trends for the theory of the justice cascade will be explored below.

\section{AMNESTY TRENDS AND THE GLOBAL ACCOUNTABILITY NORM}

The emergence of a global accountability norm under which prosecutions would replace impunity as the presumptive response to atrocity has been subject to extensive debate among 
scholars, jurists and human rights activists. ${ }^{70}$ Proponents of this norm highlight multiple 'norm-affirming events" ${ }^{71}$ to support its existence. These events include the enactment of international conventions such as the Rome Statute 1998, the judgments of international and hybrid tribunals on customary international law relating to international crimes, the speeches of officials of national governments and intergovernmental bodies acknowledging the norm, and the enactment of domestic legislation. ${ }^{72}$ Since the end of the Cold War, there is ample evidence of these types of events supporting the development of a global accountability norm. However, as the data in the previous section indicates, amnesty laws continue to be enacted by states facing political crises. This suggests that the global accountability norm has not yet reached the point where it has 'become so widely accepted' that it is 'internalized by actors' and has achieved 'a "taken-for granted" quality that makes conformance with [it] almost automatic'. ${ }^{73}$ Nonetheless, its emergence may be impacting upon amnesty trends.

When global trends in amnesty law enactment were analysed for the years from 1979 to 2011 , the data indicated that the rate of amnesty laws had remained steady throughout the period despite developments in accountability. At face value, these findings appear to undermine the existence of a 'justice cascade' in which according to Sunstein 'societies are

\footnotetext{
${ }^{70}$ See eg Decision on challenge to jurisdiction: Lomé Accord Amnesty in Prosecutor v Morris Kallon, Brima Bazzy Kamara, SCSL-2004-15-PT-060-I, SCSL-2004-15-PT-060-II, Appeal (13 Mar. 2004), para 73; Prosecutor v Anto Furundzija, Case No. IT-95-17/1-T, Judgement (10 Dec. 1998).

${ }^{71}$ Ellen L. Lutz and Kathryn Sikkink, "International Human Rights Law and Practice in Latin America,” International Organizations 54, no. 3 (Summer 2000, 2000): 633-659; Lutz and Sikkink, The Justice Cascade $1-34$.

${ }^{72}$ Lutz and Sikkink, "International Human Rights Law and Practice in Latin America" 655-6.

${ }^{73}$ Martha Finnemore and Kathryn Sikkink, "International Norm Dynamics and Political Change," International Organizations 52, no. 4 (1998): 904.
} 
presented with rapid shifts towards new norms'. ${ }^{74}$ However, as the author has argued elsewhere ${ }^{75}$ the sharp increase in the rate of amnesty laws during the 1970 s and their endurance over the past thirty years may indicate a move away from lawlessness and 'de facto’ impunity, where states simply failed to prosecute, towards an increasingly legalistic approach, in which states use law, in the form of amnesty legislation, to address legacies of past crimes. Arguably, these changes could indicate increasing recognition of international legal obligations relating to the duty to investigate and prosecute, both among human rights abusers causing them to seek amnesties, and among transitional governments. If this is the case, it would then be expected to eventually cause a decline in the number of amnesty laws.

When the global trends in amnesty introduction were analysed just for the past decade, this research found that, in contrast to the longer time period, the rate of amnesty laws has in fact decreased. In addition, where amnesty laws are proposed or enacted today there are often met by 'social disapproval' from international civil society, ${ }^{76}$ intergovernmental human rights bodies, ${ }^{77}$ and even from governments of other states. ${ }^{78}$ This disapproval can be expressed in written or oral statements, or in some cases by threats to

\footnotetext{
${ }^{74}$ Cass R. Sunstein, Free Markets and Social Justice (Oxford: Oxford University Press, 1997) 38.

${ }^{75}$ Mallinder, Amnesty, Human Rights and Political Transitions.

${ }^{76}$ Amnesty International, 'Uganda: Agreement and Annex on Accountability and Reconciliation falls short of a Comprehensive Plan to End Impunity' (London: Amnesty International, 2008); Amnesty International, 'Kenya: Concerns about the Truth, Justice and Reconciliation Commission Bill' (London: Amnesty International, 2008); Sara Darehshori, Selling Justice Short: Why Accountability Matters for Peace (New York, NY: Human Rights Watch, 2009).

${ }^{77}$ UN High Commission on Human Rights, 'Report from OHCHR Fact-finding Mission to Kenya, 6-28 February 2008' (Geneva: OHCHR, 2008); Diane F. Orentlicher, Rule-of-Law Tools for Post-Conflict States: Amnesties (Geneva: OHCHR, 2009).

${ }^{78}$ Mallinder, Amnesty, Human Rights and Political Transitions ch 8.
} 
withhold support for transitional justice projects. For example, the UN refused to cooperate with the Commission for Truth and Friendship that was jointly established by Indonesia and Timor Leste as the commission was empowered to 'recommend amnesty for those involved in human rights violations who cooperate fully in revealing the truth'. ${ }^{79}$ Sunstein has argued that the production of social disapproval indicates that a 'tipping point' has been reached, and that the costs of expressing new norms have become lower than adherence to the old norm. ${ }^{80}$ There are, however, several reasons to be cautious in pronouncing that the global accountability norm's 'tipping point' has arrived.

Firstly, although the rate of amnesty laws has declined in last decade, this is due primarily to a drop in the number of amnesty laws in 2008 and 2009. If only the years from 1999 to 2007 are considered the decline does not appear to be pronounced. In addition, the increase in the number of amnesty laws enacted between January 2010 and June 2011 suggests that the recent decline was an anomaly rather than a sustained trend. Overall, the data reveals that amnesty laws continue to be enacted by states facing political crises, and as a result, it is too early to determine whether the decline in the rate of amnesty law enactment over the past decade represents a lasting change in norm adherence among states.

Secondly, as the global accountability norm should encourage an increase in support for trials for serious violations of human rights, its existence would be expected to result in these crimes increasingly being excluded from amnesty legislation. As the data above indicated, since 1979 the rate of amnesty laws excluding these crimes has indeed increased,

\footnotetext{
${ }^{79}$ Commission for Truth and Friendship, Terms of Reference (9 March 2005), para 14. See eg “Indonesia, East Timor Seal Deal on Atrocities Despite UN Opposition,” Agence France Presse (9 March 2005); “UN Demands Indonesia Re-Try Military Officers East Timor Killings,” ABC Radio Australian (30 June 2005).

${ }^{80}$ Sunstein, Free Markets and Social Justice 38.
} 
but so too has the rate of amnesties including serious human rights violations. Overall, there is little difference between the rates for including or excluding these crimes.

Thirdly, social disapproval of amnesty laws expressed by governments and intergovernmental bodies does not represent condemnation of all forms of amnesty in political transitions. For example, amnesty laws for political prisoners or to facilitate the return of refugees still have strong international support. ${ }^{81}$ Social disapproval is triggered primarily in relation to amnesties for serious human rights violations. However, even this disapproval is rarely consistent. For example, some transitional states, such as Kenya and Nepal have been subject to substantial international pressure to investigate and prosecute, whereas amnesties enacted in other states have been largely overlooked even where they were granted for serious crimes. ${ }^{82}$ Furthermore, donor states that admonish developing countries for proposing amnesty legislation for serious human rights violations generally do so without applying the same condemnation to their own pre-existing amnesty legislation. ${ }^{83}$

\footnotetext{
${ }^{81}$ See eg UNHCR, Legal Safety Issues in the Context of Voluntary Repatriation, UN Doc EC/54/SC/CRP.12 (Geneva: UNHCR, 7 June 2004) para 12.

${ }^{82} \mathrm{Eg}$ an amnesty measure contained in paragraph 445 of the Constitution of the Republic of the Union of Myanmar, 2008 preventing any legal proceedings against 'any member of the Government, in respect of any act done in the execution of their respective duties', attracted little international condemnation despite the regime's appalling human rights record.

${ }^{83}$ For example, in UN Security Council debates on post-conflict justice, countries such as France, Spain and Algeria, all emphasised the importance of prosecutions for serious human rights violations. Yet France and Spain both have amnesty laws relating to past serious human rights violations, which remain in effect, and Algeria has introduced two amnesty laws within the past decade, albeit with some limited restrictions on the crimes to which they apply. UNSC, 'In Presidential statement, Security Council reaffirms "vital importance" of United Nations' role in post-conflict reconciliation' (27 January 2004) Press release SC/7990.
} 
In recent years, there have also been cases of strong international support for amnesty processes. For example, during the final stages of the conflict between the Tamil Tigers and the Sri Lankan government in 2009, international actors made statements endorsing an amnesty for surrendering insurgents. ${ }^{84}$ These statements of support did not refer to the need to prosecute serious human rights violations that had been committed during the conflict. In addition to statements of support, some amnesty processes receive financial backing. For example, the Ugandan Amnesty Act 2000, which grants amnesty for all conflict-related crimes committed by insurgents fighting against the government, including the atrocities committed by the Lord's Resistance Army, has consistently received financial support from international donors for its implementation. ${ }^{85}$ These endorsements of amnesties for serious crimes appear not to have been motivated by a desire for impunity, but rather a recognition of the role that amnesty can play in encouraging combatants to surrender and disarm.

Fourthly, states have consistently failed to prohibit amnesty laws in international conventions. For example, during the Rome Conference delegates debated a range of proposals relating to amnesty laws, but were ultimately unable to reach a consensus on prohibiting them in the ICC Statute. As a result, the Statute contains no reference to amnesty

\footnotetext{
${ }^{84}$ Eg “Co-Chairs Of Sri Lanka Peace Process Urge Tamil Tigers To End Hostilities”, RTT News, 3 February 2009; "Lay down arms, surrender - European Parliament tells LTTE", The Colombo Times, 6 February 2009; “U.N. Security Council Asks LTTE To Surrender”, RTT News, 22 April 2009.

${ }^{85}$ Eg in January 2008, the Ugandan Amnesty Commission received funding of US \$10,055,278 from a World Bank Multi-Donor Trust Fund to support its work. The donors to this fund included state parties to the ICC such as Denmark, Norway, the Netherlands, Sweden and the UK. See World Bank, Project Information Document: Uganda Emergency Demobilization and Reintegration Project (World Bank, 23 January 2008); "World Bank offers over sh3 billion to resettle former ADF, LRA Rebels" New Vision, 19 August 2008.
} 
legislation. ${ }^{86}$ Indeed, to date, the only convention to discuss amnesty laws explicitly is Additional Protocol II to the Geneva Conventions, which in Article 6(5) encourages states parties to enact the 'broadest possible amnesty to persons who have participated' in noninternational armed conflicts. ${ }^{87}$ The Commentary on the Additional Protocol asserts that this provision is 'to encourage gestures of reconciliation which can contribute to re-establishing normal relations in the life of a nation which has been divided'. ${ }^{88}$

Finally, where there is international pressure in favour of prosecutions, it can result in serious human rights violations being excluded from the scope of amnesty legislation, but this does not automatically mean that these crimes will be prosecuted. In addition, even where a prosecution policy is adopted, it is generally restricted to trials of relatively small numbers of high-ranking or notorious offenders, whilst the middle and lower-ranking offenders and their supporters escape legal accountability. This phenomenon was acknowledged by the UN Secretary General in 2004 when he noted, '[i]n the end, in post-conflict countries, the vast majority of perpetrators of serious violations of human rights and international humanitarian law will never be tried, whether internationally or domestically. ${ }^{89}$ The failure to prosecute could be due to multiple factors including a lack of evidence, of judicial and penal capacity, limited financial resources, the ongoing political and military strength of the offenders, or a

\footnotetext{
${ }^{86}$ William A. Schabas, An Introduction to the International Criminal Court, 3rd ed. (Cambridge: Cambridge University Press, 2007) 87.

${ }^{87}$ Protocol Additional to the Geneva Conventions of 12 August 1949, and relating to the Protection of Victims of Non-International Armed Conflicts (Protocol II) 1977, Art 6(5).

${ }^{88}$ Yves Sandoz, Christophe Swinarski and Bruno Zimmerman, eds., Commentary on the Additional Protocols of 8 June 1977 to the Geneva Conventions of 12 August 1949 (Geneva: International Committee of the Red Cross, 1987). para 4618.

${ }^{89}$ UNSC, Report of the Secretary-General on the Rule of Law and Transitional Justice in Conflict and PostConflict Societies (UN, 2004), para 46.
} 
decision by the government to prioritise other policies, such as development and security, over the pursuit of justice. Governments facing these conditions may wish to prosecute past crimes and therefore decide to exclude international crimes from amnesty legislation to ensure that trials may be possible in the future, where they cannot be held immediately. However, other states may exclude international crimes from amnesty legislation to conform to international pressure, rather than in acceptance of a global accountability norm. This rhetorical adherence to the norm can be particularly apparent where exclusions for international crimes are not enforced during the implementation of amnesty legislation..$^{90}$

The existence of a norm is not dependent on individuals or countries consistently adhering to it. Indeed, Lutz and Sikkink argue that '[j]ustifying norm breaking may ... be a norm-affirming event, if in making the justification, the actor recognizes the existence of the norm and explains why it was not possible to abide by the norm in particular circumstances' ${ }^{91}$ However, where states enact amnesty laws for serious human rights violations today, they rarely acknowledge the existence of a global accountability norm. Instead, they argue that the amnesty is necessary to bring peace and promote reconciliation. These rationales are often echoed by international actors who support and fund amnesty processes. This therefore casts doubt on the extent to which a global accountability norm has emerged.

\footnotetext{
${ }^{90} \mathrm{Eg}$ In the 1999 Algerian amnesty law, offenders who had committed crimes involving 'the death or permanent disabling of a person, rape, or the use of explosives in public places' were excluded from the amnesty. However, victims' rights groups claimed that the probation committees, which administered the amnesty processes, tended to exonerate 'repentis' after a cursory examination. As a result, suspected assassins were reportedly cleared to return home without punishment. See Amnesty International, Algeria: Truth and Justice Obscured by the Shadow of Impunity (London: Amnesty International, 2000).

${ }^{91}$ Lutz and Sikkink, International Human Rights Law and Practice in Latin America 655-6.
} 
As the data above illustrates there are regional divergences in amnesty trends. In particular, the Americas region has undergone the steepest decline in the rate of amnesty law enactment and during the last decade, fewer amnesty laws were enacted in this region than elsewhere in the world. In addition, unlike amnesty laws enacted in the Americas during the 1970s and 1980s, amnesties in this region are now less likely to include serious human rights violations than to exclude them. ${ }^{92}$ This data supports the conclusion that a 'justice cascade' has developed in this region. Lutz and Sikkink have suggested that this may be due to the region's 'tradition of commitment to international law and human rights norms'. They further argued that '[b]ecause of this preexisting, well-established normative framework, international enforcement pressures resonated domestically as external pressures reinforced domestic values'. ${ }^{93}$ The data presented above also indicates that similar trends have been taking place in Europe and Central Asia, due to the ongoing conflicts and political repression in the Newly Independent States and the Caucasus region of Russia, these trends are not yet as pronounced as in the Americas. In contrast, the existence of a 'justice cascade' is less pronounced in Asia and Sub-Saharan Africa, as in these regions the rate of amnesty laws has remained high and many of the amnesty laws enacted grant immunity to perpetrators of crimes under international law.

\footnotetext{
${ }^{92}$ In addition, the only amnesties in the Americas that have addressed serious human rights violations in the past decade, have been the laws adopted in Colombia to reintegrate members of the Autodefensas Unidas de Colombia (AUC), a right-wing paramilitary organisation. These laws are conditional on the offenders disarming and disclosing their truth about their criminal actions. However, the laws distinguish between offences, with perpetrators of serious human rights violations receiving alternative punishments rather than amnesty. See InterAmerican Commission on Human Rights, Report on the Implementation of the Justice and Peace Law: Initial Stages in the Demobilization of the AUC and First Judicial Proceedings (Washington D.C.: Inter-American Commission on Human Rights, 2007).

${ }^{93}$ Lutz and Sikkink, International Human Rights Law and Practice in Latin America 659.
} 


\section{CONCLUSION}

Support for a global accountability norm among human rights activists and scholars has caused amnesty laws for serious human rights violations to become increasingly controversial in recent decades. However, much of the support for this norm has focused on the surge in the number of prosecutions for perpetrators of mass atrocity, but has failed to take into account global and regional trends in amnesty law enactment. Indeed, as this chapter has argued, until recent years, there have been surprisingly few large-N comparative studies of amnesty laws. Where these trends are explored using the Amnesty Law Database, they indicate that over the past thirty years amnesty law enactment has continued at a steady rate. In addition, throughout this period, although the number of new amnesty laws excluding international crimes has increased, so too has the number of amnesties including such crimes.

This chapter has argued that these trends cast doubt on the existence of the global accountability norm, particularly where the enactment of amnesty laws receives diplomatic and financial support from international organisations and donor states. Although such support has yet to be systematically documented, it seems that it is particularly forthcoming where the amnesty is enacted in the midst of ongoing conflict to encourage combatants to surrender and disarm. This suggests that despite the development of international criminal law and transitional justice, a belief persists within states and the international community that in times of extreme violence, amnesty may be a necessary compromise to achieve peace. 